\title{
KOMODIFIKASI MODEL ENDORSE DALAM INDUSTRI BUDAYA FASHION DAN KOSMETIKA
}

(Hiperrealitas Fashion Endorse pada Produk Kosmetik dan Busana Remaja

di Media Sosial Instagram)

Oleh:

1).Radita Gora, ${ }^{2)}$.Sandra Olifia

Ilmu Komunikasi - ${ }^{1), 2)}$.Universitas Satya Negara Indonesia

\begin{abstract}
ABSTRAK
Media sosial sebagai bagian dari budaya populer bukan hanya digunakan oleh khalayak luas untuk menampilkan suatu identitas diri melalui perwajahan di internet, melainkan juga dimanfaatkan sebagai sarana berbisnis global. Seperti halnya produk fashion di media instagram sebagai sarana promosinya, termasuk menjadikan publik amatir sebagai model endorse untuk produk fashion dan kosmetika. Namun kegandrungan para remaja menjadi modelini kemudian terlihat sebagai bentuk pemanfaatan tubuh sebagai 'alat jual' untuk mempromosikan produk dan meningkatkan nilai jual produk yang dipromosikan. Sehingga dalam penelitian ini memfokuskan pada persoalan komodifikasi remaja sebagai model endorse di media sosial instragram yang menjadi salah satu media sosial populer di masyarakat. Teori yang digunakan dalam penelitian ini menggunakan Teori Simulacra menurut perspektif Baudrillad dalam kebudayaan modern. Pendekatan riset dalam penelitian ini adalah dengan metode Semiotika. Hasil penelitian menunjukkan bahwa pemaknaan terhadap tanda pada iklan produk, penggunaan model yang tidak dikenal bagi pihak produsen diuntungkan dengan model amatir yang memiliki perawakan yang mumpuni serta dibayar murah dan bisa mendatangkan keuntungan agar mampu memikat pelanggannya untuk mencoba memakai produk yang ditawarkan dan berusaha untuk menyerupai. Sehingga aspek infrastruktur ini sebagai bagian kekuatan kapitalis dalam mendatangkan keuntungannya serta bentuk ideologis penanaman kesadaran palsu tentang prestise individu.
\end{abstract}

Kata Kunci: Endorse, Budaya Populer, Komodifikasi, Semiotika

\section{PENDAHULUAN}

Industri fashion dan kosmetika hingga saat ini masih merajai item-item produk yang ditawarkan di dalam $e$ commerce. Vendor-vendor baru terus bermuncula di situs jual-beli produk mengingat aktivitas atau kegiatan promosi di media sosial saat ini gencar dilakukan mengingat beberapa pihak menilai bahwa promosi yang dilakukan di media sosial efektif dan pengguna sosial media aktif terus bertambah dan berkembang. Hal ini tentunya juga menjadi bagian dari individu yang paritisipatif dalam kegiata jual beli 
secara online lantaran internet adalah ladang bisnis baru bagi pebisnis muda atau pebisnis pemula. Selain itu aktivitas penawaran produk atau perdagangan di media sosial mudah untuk dilakukan lantaran adanya bentuk penawaran yang dilakukan tanpa memperlihatkan wajah si produsen, kemudian platfom teknologi yang digunakan pun juga efisien dengan perangkat mobile technology dengan harga yang beragam dan juga terjangkau. Sehingga dari sini memudahkan bagi para produsen baru untuk memasarkan produknya.

Pengguna social mobile dan social media aktif yang terus meningkat mengingat pada tahun 2018, pengguna media sosial di dunia mencapai 3.196 Miliar dari penetrasi $42 \%$, menurut data Hootsuite we are social, serta pengguna internet aktif pada tahun 2018 sebesar 4.021 Miliar daripenetrasi 53\% dan juga beriringan dengan terus bertambahnya situs jual beli online dengan menawarkan sharing business economy untuk keuntungan dan bagi hasil, serta situs yang digunakan bukan hanya digunakan untuk kepentingan pebisnis lama, namun juga bisa diterapkan bagi para pebisnis muda dan amatir yang semakin dimudahkan dengan beragam teknologi komunikasi dan informasi digital serta kemudahan fasilitas penyedia fitur-fitur lengkap dan baru didalamnya, sehingga juga memudahkan bagi produsen untuk bisa terus kontak dengan penjualnya.

Sebagian besar pelaku transaksi e-commerce melalui toko online masih mendominasi transaksi bisnis fashion. Sebagian besar responden mengakui bahwa berbelanja produk fashion melalui e-commerce lebih mudah. Hal ini terungkap dalam survei bisnis e-commerce yang dilakukan Idea atau Asosiasi Ecommerce Indonesia. Dalam survei ini sekitar 78 persen responden mengakui berbelanja fashion melalui ecommerce. Angka ini di atas transaksi barang lainnya seperti ponsel yang mencapai 46 persen dan benda-benda elektronik lainnya yang mencapai 43 persen dari total responden.

Country Head Google Indonesia, Rudy Ramawy, mengatakan kebiasaan ini karena tidak ada perbedaan kelas antar masyarakat dalam membeli baju melalui transaksi online. Masyarakat kelas menengah bawah bisa saja membeli baju melalui toko online. Tidak ada strata kelas dalam pembelian barang fashion melalui e-commerce, jadi mereka biasanya sungkan ketika membeli di Mall yang mewah, dan menjadi lebih luwes ketika membeli barang di toko online. Cara berbelanja melalui online juga mengubah kebiasaan masyarakat indonesia dalam berbelanja. Perkembangan internet mengubah cara pandang seseorang dalam membeli barang. Selain itu, para responden mengatakan bahwa belanja melalui toko online dianggap lebih mudah. Sekitar $72 \%$, menurut data google Indonesia tahun 2017, mengatakan bahwa responden mengaku mempersingkat waktu ketika melakukan belanja online atau online shopping. Banyak alasan lainnya, seperti dapat dikirimkan ke rumah dan tidak harus berpergian ke berbagai daerah, ini yang membuat pertumbuhan bagi transaksi online.

Ramainya pengguna $e$ commerce di Indonesia membuat nilai transaksinya terus bertumbuh. Menurut Bank Indonesia, nilai transaksi ecommerce pada tahun 2014 mencapai US\$2,6 miliar atau setara dengan Rp34,9 Triliun. 
Berdasarkan data Asosiasi Pengusaha Ritel Indonesia, pelaku ritel di Indonesia maupun di berbagai negara saat ini sedang berupaya merangkul pendekatan multichannel atau offlineto-online $(\mathrm{O} 2 \mathrm{O})$. Hal ini dilakukan untuk memenuhi ekspektasi pelanggan sekaligus memenangkan perebutan pangsa pasar.

Fashion dan kosmetika, bagi masyarakat modern tidak lagi dianggap sebagai pemenuhan kebutuhan sekunder, namun juga dipandang sebagai kebutuhan primer yang harus terpenuhi. Sehingga penawaran trend busana-busana baru dengan beragam variasi atau model-model yang beragam dan dari berbagai versi, memudahkan bagi para konsumen atau khalayak luas dalam memilih produk meskipun penawaran produk dan jenis busana atau kosmetik yang ditawarkan memiliki banyak jenis dan beragam. Sehingga keberadaan fashion dan produk kosmetik terus menjadi incaran bagi para khalayak luas terutama yang tersegment pada remaja di tingkat pendidikan Menengah dan pendidikan tinggi. Tak ayal produk-produk fashion yang terus membanjiri konten pada ruang-ruang portal penjualan produk di situs jual beli online bisa dikatakan non stop karena selain model-model busana baru yang dikembangkan oleh para desainer, pengembang bisnis tekstil, serta para retailer atau re seller, juga terjadinya persaingan yang begitu ketat antar produsen, baik produsen amatir dengan memanfaatkan penawaran produk dengan media digital ataupun persaingan dengan para produsen konvensional.

Upaya
memenangkan
persaingan bisnis tersebut, maka

produsen baju pun berlomba-lomba untuk membuat media promosi dengan desain iklan yang menarik dimedia digital, eye catching serta menggunakan model-model yang memiliki perawakan dari wajah atau badan yang sesuai dengan penangkapan kamera atau dikenal dengan istilah camera face dan memiliki perawakan yang menjual. Sehingga dengan begitu dapat mendukung produk agar mudah terjual dengan terus mendengungkan brand (merek) produk di media komunikasi massa digital karena ada ketertarikan konsumen atau calon konsumen terhadap model ataupun produk yang dijual. Keberadana media digital online bisa dikatakan sebagai perangkat dari media baru yang perlahan mulai mendominasi masyarakat dan juga media lama. Alhasil kapasitas penggunaan media baru pun juga terus meningkat. Bahkan masyarakat yang selalu terhubung dengan jaringan mobile selalu terkoneksi dalam hal komunikasi secara terus menerus. Sehingga interkoneksi dengan pelanggan pun akan mudah dilakukan termasuk menunjukkan objek branding juga semakin mudah dijangkau untuk memikat para clon pelanggan atau pelanggan itu sendiri.

$$
\text { Penggunaan model-model }
$$
endorse pada produk busana, kosmetik dan lain sebagainya kini mulai dipopulerkan kembali sejak adanya kegiatan marketing elektronik dengan menggunakan media online. Endorse sendiri sebenarnya bukan praktik baru dalam aktivitas marketing. Apabila mengacu pada vendor-vendor lama atau yang sudah menjadi pebisnis lama di bidang fashion dan kosmetika, biasanya 
paradigma konvensional yang digunakan adalah dengan berpromosi memanfaatkan model terkenal atau selebritis terkenal. Adapula yang meneggunakan model berkelas yang memiliki potensi fisik yang memadai, glamour serta dari segi perwajahan yang benar-benar memiliki nilai berkelas atau menunjang dari sisi karirnya. Sehingga dalam hal ini menjadikan model-model busana dan kosmetik memiliki nilai jual dan sebagai alat komoditi yang diyakini menunjang untuk memikat para calon konsumen atau para konsumen melalui ketertarikan dengan sang model busana yang cantik atau tampan yang kemudian memberi stimulus kepada khalayak agar bisa mengenakan busana seperti yang dikenakan model agar terlihat seperti model tersebut. Sehingga dari sini kemudian para model-model busana dan kosmetika kemudian menjadi alat komoditi yang ditampilkan dalam visualisasi media iklan yang dimuat di media massa agar dapat memikat pelanggan.

Seiring berjalannya waktu dengan adanya media sosial dan perangkat media digital yang mudah dijangkau atau dimiliki oleh masyarakat dari semua kalangan, potensi masyarakat untuk membangun brand pun juga dilakukan dengan cara beragam dan kreatif. Bahkan dengan adanya media sosial, blog dan lain sebagainya yang terkoneksi dengan jaringan online, kegiatan promosi produk pun mudah dilakukan serta membangun publisitas produknya dengan gaya storytelling. Bahkan strategi promosi dengan low budget (pembiayaan murah) pun beragam serta dengan cara yang kreatif, sehingga pesan dalam kegiatan promosi pun menjadi bernilai persuasif serta cepat diterima dan ditangkap oleh khalayak luas, mengingat pengguna ponsel pintar di Indonesia juga terus meningkat dan tingkat konsumsi khalayak yang juga terus meningkat, sejak diperkenalkannya beragam aplikasi situs online di ponsel dan juga para akun pengguna media sosial yang terus meningkat.

Kreatifitas para produsen busana dan kosmetik pun tak canggung dalam menampilkan model endorse biasa, tak dikenal atau bukan figur publik untuk menjadi model busana dan kosmetik yang dipromosikan lewat media sosial, mengingat free promotion di media sosial yang diutamakan untuk menekan budget promosi dan memperkenalkan brand ke masyarakat. Model endorse biasanya menggunakan objek manusia yang secara perwajahannya merupakan perwajahan kamera (camera face), perawakan yang stabil dan memiliki rupa atau gaya perawakan yang menunjang untuk promosi produk dengan mengenakan busana dari produk yang akan dipasarkan, kemudian dimuat atau ditampilkan di media sosial atau portal web online e commerce. Tujuan dari penggunaan model endorse ini pun sama dengan paradigma sebelumnya yaitu bertujuan untuk memikat perhatian calon customer agar membeli produk tersebut. Model endorse pun di satu sisi merasa memiliki prestise dalam dirinya karena berharap dari wajahnya akan dikenal banyak orang dan juga berharap bisa menjadi bagian dari aktivitas pemasaran dan bisa 
mendatangkan keuntungan, meskipun bukan keuntungan secara utuh. Penganggaran untuk model endorse ini pun tidak mengeluarkan jumlah biaya terlalu besar karena masih dinilai amatir.

Model endorse pada dasarnya tidak memahami bahwa penjualan produk dengan memanfaatkan dirinya sebagai jasa ikon promosi produk busana atau kosmetika akan memiliki profit yang tinggi dan menghasilkan kualitas penjualan yang bagus. Kualitas penjualan produk dan profit dari penjualan produk pada dasarnya hanya diketahui oleh pihak pemilik usaha atau produsen. Sebagian besar pelaku usaha fashion melalui e commerce meyakini bahwa penggunaan endorse mampu mendongkrak penjualan produk busana, di satu sisi para pelaku usaha pun kadang tidak canggung untuk memberikan kompensasi rendah kepada pihak model endorse agar dapat memperoleh keuntungan yang besar dari produk yang dijual. Alhasil, dapat terlihat bahwa upaya untuk mengeksploitasi keberadaan model endorse pun semakin terlihat, lantaran tidak memanfaatkan personal-personal yang memiliki talenta bernilai lebih atau yang benar-benar sebagai sosok figur yang dikenal oleh banyak orang. Sehingga upaya untuk membangun brand produk pun semakin mudah dilakukan dengan pembiayaan yang rendah. Kadang perwajahan pun tidak begitu terlalu dipermasalahkan, maupun bentuk tubuh dalam pemuatan di media promosi, karena hal ini juga didukung dengan teknologi komputer, ataupun aplikasi ponsel yang mendukung untuk melakukan proses pengeditan terhadap wajah dan tubuh seperti melalui proses Digital Imaging.

Adapun keberadaan busana yang dikenakan oleh model endorse juga bertujuan untuk ditiru oleh khalayak luas dan membuat masyarakat meniru style busana yang dikenakan oleh model yang dimana visualisasi promosi produk tersalurkan melalui media sosial. Sehingga upaya promosi melalui media sosial pun dikemas dan dibangun se kreatif pada konten pesannya agar bisa semenarik mungkin di media sosial seperti halnya media sosial visual instagram dan mampu membentuk kesadaran palsu bagi khalayak, sehingga tersimulasi denganmempercayai ouput pola fashion dan kosmetik yang sesuai dengan konten promosi dan kualitas hasil yang bersifat fiksi. 


\section{LANDASAN TEORITIAS}

\section{Hiperrealitas dan Simulacra}

Kajian realitas pada media mencoba mengkritisi bagaimana konten media tidak selalu bersinggungan antara yang nyata (realitas) dengan tidak nyata. Sherry Turkle (1997) melukiskan tentang realitas virtual sebagai berikut: realitas virtual memberikan gambaran terhadap kehidupan yang lebih nyata dibandingkan kehidupan nyata itu sendiri". Dalam artian yang nyata lenyap karena longsoran simulasi dan yang muncul adalah realitas yang mengatasi realitas real (hypereality), realitas yang lebih cantik dari yang cantik, lebih benar dari yang benar. Baudrillad (1993) mengatakan bahwa Hiperrealitas tidak diproduksi, akan tetapi selalu siap direproduksi. Baudrillad memberikan contoh di mana talkshow televisi larut ke dalam kehidupan dan kehidupan larut ke dalam televisi. Begitu pula iklan dan televisi menjadi simulasi dalam kehidupan individu di era kemajuan teknologi seperti saat ini. Kehidupan menjadi simulasi dan sebaliknya simulasi menjadi kehidupan. (Baudrillad, 2011: 120).

Dalam bukunya Symbolic Exchange and Death, Baudrillad mengemukakan konsep "kode" yang dilihatnya begitu penting dalam suasana modern akhir. Konsep kode ini jelas berkaitan dengan munculnya era komputer (komputerisasi) dan digitalisasi. Menurutnya kode cukup mendasar dalam berbagai ilmu seperti fisika, biologi dan ilmu pengetahuan alam lainnya (kode biner dalam teknologi komputer, kode DNA dalam biologi, kode digital pada televisi dan dunia rekaman dan kode dalam teknologi informasi), dimana ia memberi kesempatan berlangsungnya reproduksi sempurna dari suatu objek situasi; karena itu kode bisa mem bypass sesuatu yang real dan membuka kesematan bai munculnya realitas yang disebutnya dengan hyperreality (Hiperrealitas). (Baudrillad, 2011: 89).

Baudrillad menggambarkan munculnya sebuah simulasi; karena masyarakat posmodern yang diorganisasi melalui simulasi, di mana model, kode, komunikasi, informasi, dan media adalah penyebab patahan radikal dengan masyarakat modern. Penelitiannya tentang simulasi, implosion, hiperrealitas dan berbagai dampak komunikasi, informasi, dan teknologi media baru membuka jalan baru dalam teori sosial kontemporer dan menantang ortodoksi yang dominan. (Lubis, 2016: 180).

Dalam era Simulasi segala sesuatu hancur menjadi sesuatu yang lain. Segala sesuatu meledak (imploding) ke sesuatu yang lain. Impuls atau peledakan adalah penyusutan ke dalam masing - masing yang lain, peringkasan yang luar biasa, penghancuran dua aras tradisional ke dalam aras lain.

Zaman kode telah menggantikan zaman tanda. Hubungan antara kode dengan reproduksi reproduksi yang asli. Pada "kode" mensyaratkan bahwa objek yang dihasilkan sebagaimana jaringan pada 
bologi bukan seperti salinan sebagaimana bisa dipahami, di mana salian sebagai reproduksi dari objek yang asli. Perbedaan antara salinan dengan yang asli justru menjadi berlebihan. Realitas semu (virtual reality) komunikasi global, hologram, dan seni adalah wilayah yang menunjukkan bentuk simulacra.

\section{Budaya Populer}

Secara tradisional, ide budaya populer merujuk pada lawan dari budaya tinggi dan/atau produksi massal budaya komoditas dari kapitalisme konsumer.Dalam budaya populer dianggap lebih rendah daripada budaya tinggi Seni dan musik klasik di satu sisi dan budaya rakyat yang otentik di sisi lain. Para pembela distingsi (pembeda) antara budaya tinggi dan budaya populer mendasarkan pada pembeda yang dibuat dan ditunjukkan oleh budaya populer. Budaya populer seringkal dituduh menstandarisasikan dan memerosotkan kualitas seni dan budaya sehingga seni-budaya konformis. Seperti kita lihat pada praktik seni lukis tradisional saat ini mulai tergerus dengan seni lukis digital dengan memanfaatkan eknologi komputer. Keberadaan komputerisasi sudah mulai menggantikan beberapa aktivitas seni masyarakat. Orang menggambar tidak perlu lagi menggunakan bahan-bahan alamiah yang mungkin sulit untuk diterapkan untu masarakat saat ini, selain itu juga merepotkan karena harus berkotorkotor dengan perangkat lukis, namun dengan komputerisasi semua itu tidak perlu terjadi, bahkan dapat memanipulasi gambar sedemikian rupa. (Strinati, 2016: 7).

Meskipun budaya populer kontemporer pertama-tama berupa barang atau jasa yang diproduksi secara komersial, namun banyak penulis kajian budaya yang berargumen bahwa audiens membentuk sendiri makna yang mereka mau dari teks-teks komoditas yang tersedia. Dengan kata lain, pembaca atau audiens teks-teks budaya membawa dan menggunakan kompetensi kultural serta sumber daya diskursif yang mereka punyai untuk mengonsumsi komoditas-komoditas. Jadi, budaya populer bisa dilihat sebagai gugus makna dan praktik yang diproduksi oleh audiens pada saat (momen) konsumsi. (Sugiharti, 2017: 44).

Media massa, budaya populer, dan artifak-artifaknya (seperti bentukbentuk rekaman, buku, majalah, merchandise, acara televisi, film dan bintangnya) adalah produk-produk budaya yang menandai perkembangan masyarakat pasca industri. Dalam kehidupan sehari-hari satu hal yang seringkali menjadi ciri yang memadai penggemar adalah berkembangnya perilaku adiktif atau kecanduan untuk terus mengkonsumsi budaya populer global yang digemarinya layaknya social opium (candu atau narkotika sosial). Di kala waktu senggang bahkan di waktu kerja sekalipun, sudah menjadi kebiasaan para reamaja saat ini untuk meluangkan waktu membuka laptop termasuk kecanduan terhadap handphone mereka untuk melihat percakapan, komentar dan informasi lain yang mereka gemari yang 
bermunculan pada konten di media sosial. Perassaan dan kekhawatiran agar tidak ketinggalan informasi, menyebabkan anak-anak muda urban menjadi adiktif untuk terus mengikuti perkembangan informasi tentang budaya populer global yang mereka gemari.

Teks-teks budaya populer mereplikasi diri dalam bentuk paratext, seringkali membuat remaja makin masuk kedalam dunia rekaan dari sang creater atau si pembuat aplikasi pada media. Tentunya kapitalis memanfaatkan hal tersebut untuk mencari keuntungan. Dalam kajian budaya memahami budaya populer sebagai medan persetujuan dan perlawanan guna meraih (memenangkan) makna-makna budaya. Dalam pengertian ini, kajian budaya melihat dan menempatkan konsep budaya populer secara politis sebagai medan perjuangan merebut makna dan pemaknaan; atau, dengan kata lain, arena di mana hegemoni budaya diperoleh atau ditantang. (Strinati, 2016: 15).

\section{Komodifikasi}

Studi budaya sudah cukup lama menggeluti persoalan ini diantraanya dengan melihat secara kritis proses komodifikasi budaya, di industri budaya mengubah orang dan makna menjadi komoditas yang berguna dan bisa dijual. Komodifikasi adalah proses yang erat di kaitkan dengan kapitalisme di mana objek-objek, kualitas-kualitas, dan tanda-tanda diubah menjadi komoditas. Komoditas sendiri dipahami sebagai sebauh barang yang tujuan utama keberadaannya adalah untuk dijual di pasar.

Pada studi media, kajian komoditas sering dimanfaatkan untuk beragam riset yang mencakup objek iklan (seperti objek orang tua, anakanak, laki-laki dan perempuan pada suatu iklan), kemudian objek orang pada suatu tayangan televisi untuk menaikkan rating sebuah tayangan film, kemudian komoditas konten pada pemberitaan seperti kasus pelechan atau kekerasan pada perempuan dan anak kemudian konten politik dan lain sebagainya. (Barker, 2014: 41).

\section{METODE PENELITIAN}

\section{Paradigma Penelitian}

Metode penelitian yang digunakan dalam penelitian ini adalah dengan menggunakan penelitian kualitatif melalui analisis teks media iklan promosi di media sosial dengan memaknai tanda dan simbol pada media. Analisis tekstual ini juga menyadarkan kepada peneliti dan akademisi bahwa budaya / culture yang dikreasi dan diciptakan kemudian didistribusikandan dikonsumsi adalah hasil dari konstruksi sosial yang non "given" atau "taken for granted". Dengan dasar pengetahuan inilah maka, analisis tekstual berangkat dari asumsi bahwa makna tidak tunggal tetapi multiple atau dengan istilah John Fiske (1981) makna bersifat "polysemy".(Ida, $2014: 59)$.

Paradigma penelitian yang digunakan dalam penelitian ini menggunakan paradigma kritis. Paradigma ini ingin mengoreksi 
pandangan konstruktivisme yang kurang sensitive pada proses produksi dan reproduksi makna yang terjadi secara historis maupun institusional. Paradigma kritis, sebagai suatu tradisi intelektual dengan seperangkat keyakinan dalam melihat sebuah fenomena permasalahan secara kritis dengan membedah ideologi, dan sebagai bentuk pencerahan (enlightment) produsen melalui teks maupun konteks produk di dalam pemuatannya pada media iklan promosi di media sosial.

\section{Teknik Pengumpulan Data}

Pengumpulan data pada penelitian ini, peneliti menggunakan korpus materi iklan promosi di media sosial yang termuat di Instagram dengan produsen produk busana (fashion) Roughneck dan produk kosmetika Nature Republic yang masing-masing 1 sampel yang diteliti dengan materi iklan yang telah dipilih oleh peneliti. Pada kedua produk yang disebutkan ini dipilih karena adanya fanatisme terhadap produk tersebut karena memiliki brand yang paling banyak diminati di kalangan remaja dan juga menampilkan pandanganpandangan kebaruan dalam trend fashion serta pandangan baru terhadap endorse yang ditampilkan di media sosial. Seperti halnya Roughneck yang digandrungi para remaja dengan street style yang tidak lagi terlalu menonjolkan kemewahan, kemudian pada produk Nature Republic karena produk kosmetik ini sebagai cream pembersih selain mengundang fanatisme pelanggan dalam jumlah besar hingga mengantri dari sisi penjualan termasuk maraknya kasus pemalsuan produk ini sehingga produk ini menjadi incaran distributor dan menggunakan endorse sebagai bagian dari pendukung alat jualnya.

Selain itu media sosial yang dijadikan sebagai bagian dari korpus penelitian ini adalah dengan meneliti iklan promosi yang menampilkan endorse fashion Roughneck dan Nature Republic di media sosial instagram. Selain itu didukung dengan akumulasi atau jumlah pengguna instagram aktif di dunia yang sudah mencapai 700 juta hingga tahun 2017, meskipun di Indonesia, instagram masih masuk urutan keempat untuk jumlah pengguna aktifnya menurut data Hootsuite wearesocial.org.

\section{Teknik Analisis Data}

Teknik analisis data yang digunakan pada penelitian ini menggunakan analisis semiotika model Ferdinand De Sassure dan deskripsi penyajian data melalui hasil wawancara dengan Informan yaitu salah satu endorse produk lokal di Indonesia. Adapun beberapa tahap analisis yang dilakukan:

1. Analisis tanda (sign) pada visual iklan produk Roughneck dan Nature Republic. Model analisis yang digunakan dengan model analisis semiotika dari Ferdinand De Sassure yaitu mengdeintifikasn dan memaknai signifier (petanda) dan signified (penanda). Dengan tulisan semiotiknya tentang hal ini, Baudrillad, mengikuti Saussure dan kaum strkturalis, berusaha menunjukkan tidak adanya objek yang secara terisolasi terlepas dari yang lainnya. Akan tetapi, aspek- 
aspek diferensial atau relasional menjadi cukup penting dalam upaya memahami objek-objek tersebut. Menurut Saussure, hubungan antara penanda dan petanda bersifat manasuka (arbitrer), artinya tidak ada kaitan ilmiah antara petanda dan penanda. Kearbitreran hubungan penanda dan petanda berlangsung pada walnya, kemudian menjadi permanen (stabil) ketika terjadi konvensi. (Rusmana,2014 :94). Saussure dengan tegas menandaskan bahwa tanda bahasa itu merupakan wujud psikis karena ia tidak mempertimbangkan wujud dari parole (tuturan). Ia menyarankan bahwa pengkajian ilmiah terhadap wicara dapat dan harus dilakukan, tetapi kajian linguistik yang sebenarnya ialahkajian tentang langue ; Bila kajian itu telah diselesaikan, prinsip yang sama dapat diterapkan terhadap parole. (Kridalaksana, 2005: 26).

2. Pada tahapan ini dilakukan reduksi dan penyajian data dengan melakukan pengumpulan serta interpretasi data berdasarkan hasil wawancara dengan para endorsers pada usia remaja yang rate usianya dibawah 30 tahun. Selain itu juga membangun kesimpulan berdasarkan hasil analisis data dan juga kajian pembahasan yang dikaji dalam perspektif Teori Simulacra dan juga bagaimana implementasi hiperrealitas pada iklan Roughneck dan Nature Republic.

\section{PEMBAHASAN}

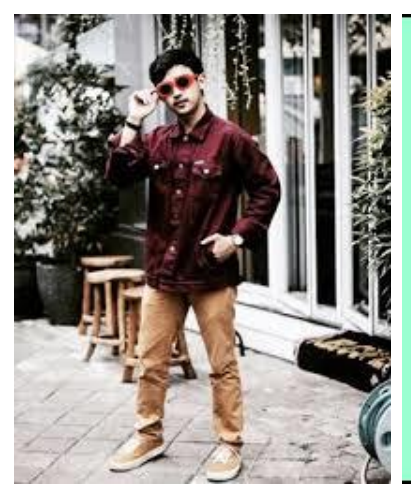

Berdasarkan

\section{Pakai Aloevera??}

\section{Muka Kinclong Bak}
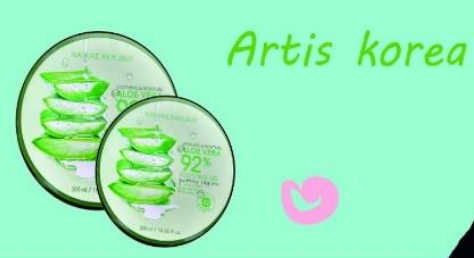

analisa hasil penelitian ini, pada produk Roughneck dan Nature Republic dengan menggunakan model analisis semiotika Saussure, dapat dijelaskan bahwa aspek Tanda yang digunakan pada produk iklan kosmetika Nature Republic dilihat dari tiga sisi, yaitu Teks, warna dan figure. Teks pada iklan Nature Republic versi wanita hijab bertuliskan "Pakai Aloevera?" sebagai sebuah teks pertanyaan kata "pakai" yang berarti menggunakan.

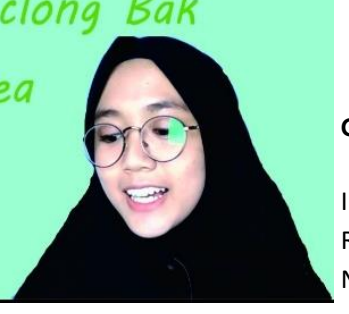

Gambar 4.1

Iklan Produk Roughneck dan Nature Republic

Sementara "Aloevera" sebagai sinonim dari tanaman lidah budaya. Dalam aspek Denotasi bahwa tanaman yang digunakan untuk perawatan herbal yang baik untuk kesehatan tubuh dan digunakan untuk perawatan pada kulit wajah dan rambut. Dalam teks pertanyaan ini mempertanyakan kegunaan dari tanaman lidah buaya. Kemudian mempertanyakan apakah ada kelayakan atau nilai kegunaan menggunakan ramuan tanaman lidah budaya. 
Pada tanda ini dimunculkan sebagai upaya untuk mengajak masyarakat atau audiens berpikir tentang kegunaan tanaman lidah buaya. Sehingga upaya mempersuasi khalayak tidak dilakukan secara langsung tentang output hasil dari penggunaan produk kosmetik ini. Namun juga untuk melakukan edukasi terhadap masyarakat agar lebih berpiki rasional dalam menggunakan produk kosmetika dan memahami bahan yang digunakan dalam ramuan herbal tersebut.

Pada teks berikutnya adalah “Muka kinclong bak artis Korea?" Pada pertanyaan masing-masing kata pada "Muka" berarti wajah yang dimaknai secara fisik atau "badan" bukan diartikan sebagai diri. Pada bahasa iklan hendaknya menggunakan penggunaan kata-kata baku yang dalam Kamus Besar Bahasa Indonesia (KBBI) penggunaan kata baku merujuk pada "Wajah" sebagai pembentukan pengucapan kata yang sebenarnya dan digunakan pada konten tertentu. Pada iklan ini terdapat kekeliruan penggunaan kata ' $m u k a$ ' yang secara harafiah dimaknai sebagai diri seperti harga diri. Sementara penggunaan kata 'wajah' adalah fisik atau badan manusia. Sementara produk kosmetika ditujukan pada nilai kegunaan untuk badan secara fisik.

Kemudian pengunaan kata 'kinclong' yang secara sinonim adalah mengkilap. Dengan makna denotasinya dapat diartikan bersih, atau tidak kusam. Hal ini juga melanggar dari sisi estetika bahasa dan eika yang tidak termasuk dalam pemenuhan kaidah bahasa yang baku seperti "wajah bersih" atau "wajah terlihat bersih". Sehingga makna dalam iklan pun menjadi jelas dan tidak rancu dengan persoalan estetika bahasa maupun etika penggunaan kata. Subjek teks perlu memandang jarak dengan kahalayak sehingga teks dapat bersifat netral. Jika teks mendekatkan pada segment tertentu, maka ada kecenderungan teks berpihak sehingga nilai kegunaan dari teks menjadi hilang.

Penggunaan kata "kayak artis Korea" kata "kayak" dapat diartikan "seperti" yang juga berlaku interpretasi umum "sama halnya" atau "menyerupai". Kemudian kata "artis" bisa diartikan sebagai pekerja seni. Namun pada kata artis disini bukan dimaknai sebagai pekerja seni secara luas, melainkan memfokuskan pada "artis sebagai selebiritis" atau dalam makna denotasinya adalah orang terkenal atau figur ternama. Hal ini menjadi berhubungan dalam penggunaan kalimat pertanyaan bahwa aspek estetika penggunaan kata, pemilihan kata, serta etika yang digunakan dalam berbicara tidak memperhatikan aspek etika dan estetikanya. Dan terlalu mengkaitkan dengan "artis korea". Dalam hal ini, ada unsur 'pemujaan' terhadap sosok artis Korea. Iklan pun menunjukkan adanya peanaman kepada khalayak sebagai tidak mempercayai aktualisasi lokal atau lebih memandang keberadaan figur dari negara lain dibandingkan figur dalam lingkup lokal, sehingga iklan pun terlihat non edukatif dengan mengatasnamakan produk Korea dan membuat khalayak agar memiliki kesadaran palsu tentang perwajahan Korea adalah yang 
sempurna dan meruntuhkan rasa kepercayaan diri terhadap lingkup lokal.

Sedangkan pada lata warna secara keseluruhan menggunakan warna latar hijau muda sebagai warna alam dalam pemaknaan denotasi yang identik dengan warna hijau dan juga warna daun. Namun warna hijau juga mengacu pada warna tanaman seperti lidah buaya yang notabene berwarna hijau muda sebagai kualitas tanaman lidah buaya yang baik.

Figur endorse pun juga tidak relevan dalam menggunakan figur perempuan berhijab dengan busana hitam. Sehingga tidak ada estetika antara penempatan figur dengan warna latar pada visual media promosinya. Begitu pula penempatan endorse pun cenderung dipaksakan dengan tidak memperhatikan estetika penampilan maupun tidak menempatkan perwajahan yang camera face dan tidak menyesuaikan konsepsi perwajahan Korea.

Produk fashion pria Roughneck versi pria remaja dengan konsep street "jalanan" tidak menempatkan posisi Endorse pada komposisi yang estetis, dan tidak memandang sinkronisasi komposisi ojek latar dengan subjek yang difoto. Pada tanda objek yang terlihat pada latar penuh dengan partisi benda-benda sekunder seperti kursi, atau tanaman dan sebuah ruangan sehingga terlihat gaya semi modern antara saat ini dengan jaman dahulu (retro).

Hal tersebut lebih terlihat dengan nuansa kecoklatan sehingga nuansa klasik atau bergaya fashion lama dengan kemasan modern hingga memunculkan kesan yang menarik dan tidak terlalu mewah serta cocok untuk digunakan untuk segmen segala remaja. Adapun penempatan posisi endorse juga tidak menempatkan posisi model secara teratur sehingga estetika model ada kecenderungan tidak bisa menampilkan pasar fashon yang sebagaimana mestinya.

Berdasarkan hasil wawancara dengan informan yang juga model endorse salah satu produk fashion pria yang cukup ternama di kalangan remaja, Syahril (20) ini mengatakan bahwa sebagai model endorse dirinya menamakan dirinya juga influencer atau pihak yang mampu mempengaruhi orang lain. Sebagai model endorse juga berada dibawah manajemen pengelolaan kinerja model dan bekerja sama dengan perusahaan-perusahaan besar untuk jasa model atau endorse busana, kosmetika,benda-benda elektronik dan lain sebagainya. Syahril mengakui bahwa terkadang dirinya dimanfaatkan untuk mempromosikan produk yang hanya dengan imbalan diberikan beberap potong baju ataupun hanya mendapatkan payment yang tarifnya bisa dibawah standar kerja. Bahkan seorang endorse pun juga harus memiliki akun instagram dan turut partisipasi dalam mempromosikan produknya melalui instagram dalam perjanjian kurun waktu yang ditentukan.

Berdasarkan seluruh kajian pembahasan yang tellah dituliskan, maka dapat dilihat bahwa ada upaya bagi instansi untuk meningkatkan 
surplus pendapatan perusahaannya dengan memanfaatkan model yang bisa dibayar lebih murah dan juga memperoleh keuntungan yang sebesarbesarnya. Selain itu ideologi kapitalis ditanamkan dengan melakukan suatu penanaman kesadaran bagi model endorse tentang eksistensi, pengenalan nama atau figur dan juga pengembangan yang tentunya dari kesemua itu adalah bertujuan untuk membangun nilai surplus secara finansial perusahaan.

Sementara dari kajian simulacra, dapat terlihat bahwa produk fashion maupun kosmetika ini membangun pesan yang bersifat persuasif untuk membentuk suatu simulasi masyarakat yang terlihat seolah tidak membedakan antara realitas fakta maupun diluar realitas. Upaya menanamkan kesadaran kepada konsumen bahwa produk semacam kosmetika nature republic memberikan keyakinan pada masyarakat bahwa dengan menggunakan produk tersebut, maka dapat memberikan perwajahan yang bersih seperti halnya figur Korea. Hal ini pun sesuai dengan perspektif fanatisme masyarakat konsumen terhadap nilai-nilai konsumtif produk dalam memilih produk. Begitu pula dengan produk Roghneck yang memberikan tentang perspektif busana remaja yang bernuansa sederhana dan bisa digunakan dalam segala situasi. Sehingga bagi remaja, untuk gaya berbusana sederhana adalah upaya untuk membangun identitas diri, namun di satu sisi juga mengajak remaja untuk hidup dalam dunai gaya (style) seperti yang digambarkan.

\section{PENUTUP}

Berdasarkan hasil analisa dan kajian pembahasan yang telah dibahas sebelumnya, maka penelitian ini dapat disimpulkan sebagai berikut:

1. Tanda pada media promosi iklan memiliki keterkaitan visual dengan nuansa remaja dan juga untuk mengajak khalayak sebagai bagian dari konsumen dengan meyakinakan kesadaran khalayak bahwa kualitas produk terlihat nyata dan bisa ditirukan penggunaan gaya dan juga meyakinkan dari kualitas produknya. Adapun tanda dan simulasi iklan mencoba untuk menanamkan kesadaran palsu kepada masyarakat tentang ouput dari kualitas produk adalah nyata dan diyakini memiliki kualitas lebih.

2. Makna tanda secara keseluruhan terlihat menitik beratkan pada warna, visual dan juga teks. Teks pada iklan instagram dan diekspose secara terbuka di media sosial tidak memperhatikan aspek estetika visual maupun estetika kata atau kalimat serta estetika dalam menampilkan figur model yang tidak teratur secara penataan sehingga terlihat seperti foto biasa dan akses persuasi produk pun menjadi terhambat. Dilihat dari warna pada foto pun juga tidak menampilkan bentuk warna elegan sehingga dilihat tanda pada warna visual iklan pun menjadi kurang menekankan pada kekuatan atau keutamaan produk.

3. Pemodelan endorse instagram disini terlihat bahwa figur model yang tidak dikenal dimanfaatkan sebagao objek atau alat komoditi bagi vendor iklan atau produsen 
dalam memasarkan produk. Dengan menekan biaya budgeting iklan atau media promosi yang berlebihan dengan menitikberatkan pada pembiayaan model, para vendor pun terlihat lebih menekan budget pada penggunaan model dengan memanfaatkan endorse remaja yang dapat dibayar lebih murah atau hanay bermodalkan penawaran eksistensi agar lebih dikenal sehingga menguntungkan bagi pihak produsen itu sendiri.

\section{DAFTAR PUSTAKA}

Baudrillad, Jean P.,2011. Masyarakat Konsumen. $\quad$ Yogyakarta: Masyarakat Konsumsi.

Barker, Chris. 2014. Kamus Kajian Budaya. Yogyakarta: Penerbit Kanisius.

Ida, Rachmah. 2014. Metode Penelitian Studi Media dan Kajian Budaya. Jakarta: Kencana Prenada Media Group.
Kridalaksana, Harimurti. 2005. Mongin Ferdinand de Sassure (18571913) (Peletak Dasar Strukturalisme Dan Linguistik Modern). Jakarta: Yayasan Pustaka Obor Indonesia.

Lechte, John.2001. 50 Filsuf Kontemporer: Dari

Strukturalisme sampai Postmodernitas. Yogyakarta: Pustaka Filsafat.

Lubis, Akhyar Yusuf. 2016. Posmodernisme: Teori dan Metode. Jakarta: Rajawali Press.

Rusmana, Dadan. 2014. Filsafat Semiotika. Bandung: Pustaka Setia.

Strinati, Dominic. 2016. Popular Culture (Pengantar Menuјu Budaya Populer). Jakarta: Pustaka Promethea.

Sugiharti, Rahma. 2017. Budaya Populer dan Subkultur Anak Muda. Surabaya: Airlangga University Press. 